\title{
Central Nervous System Depressant, Analgesic and Antidiarrheal Effects of the Seed Extracts of Dimocarpus longan Lour in Rats
}

\author{
Farhana Alam Ripa ${ }^{1^{*}}$, Mahmud Tareq Ibn Morshed", Afsana-Al-Sharmin², \\ Shahed Bulbul Papon ${ }^{2}$, Md Rafiqul Islam ${ }^{2}$ and ZaraSheikh ${ }^{1}$ \\ ${ }^{1}$ Department of Pharmacy, BRAC University, Mohakhali, ${ }^{2}$ Department of Pharmacy, Southeast University, Banani, Dhaka-1213, \\ Bangladesh \\ *For correspondence: Email: ripa.seu@gmail.com; Tel: +88-02-8912144, +88-01726216153
}

\begin{abstract}
Purpose: To assess the central nervous system (CNS) depressant, analgesic and antidiarrheal activities of the dried seed crude extracts of Dimocarpus longan Lour in rodents.

Methods: Selected pharmacological effects of the ethanol (ENLS), petroleum ether (PELS), chloroform (CHLS) and ethyl acetate (EALS) extracts of D. longan fruit seeds were investigated. CNS depressant activity was evaluated by open field and hole cross tests; analgesic activity by acetic acid-induced writhing test and formalin-induced licking test; and anti-diarrheal activity was assessed in castor oil and magnesium-induced diarrhea rat model. The extracts were given orally in a rat model at doses of 200 and $300 \mathrm{mg} / \mathrm{kg}$ body weight. Normal saline served as control in all experiment. In CNS depressant test, diazepam (1 mg/kg) was used as reference drug while indomethacin $(10 \mathrm{mg} / \mathrm{kg})$ and loperamide 2 $\mathrm{mg} / \mathrm{kg}$ ) were used as standard drugs in analgesic and antidiarrheal tests, respectively.

Results: In hole cross method, EALS showed the most effective depressant effect, viz, $1.17 \pm 0.17$ for $200 \mathrm{mg} / \mathrm{kg}$ dose and $0.83 \pm 0.31$ number of movements for $300 \mathrm{mg} / \mathrm{kg}$ dose after $120 \mathrm{~min}(p<0.01)$, whereas in the open field test, all the extracts exhibited significant $(p<0.01)$ depressant effect in relation to positive control, diazepam. In acetic acid-induced pain test, PELS gave the lowest number of writhing $(2.83 \pm 0.307)$ and the highest inhibition $(88.45 \%, 300 \mathrm{mg} / \mathrm{kg}$ dose) which was statistically significant. All the extracts also significantly $(p<0.01)$ suppressed licking activity in both phases of the formalin-induced licking test, in contrast to indomethacin. In the antidiarrheal tests, diarrheal suppression was highest at $300 \mathrm{mg} / \mathrm{kg}$ dose for all the extracts, compared with loperamide in both castor oil and magnesium sulphate induced diarrhea model.

Conclusion: The extracts of Dimocarpus longan tested demonstrated significant CNS depressant, analgesic and antidiarrheal activities in a rodent model.
\end{abstract}

Keywords: Dimocarpus longan Lour, CNS depressant, Analgesic, Anti-diarrheal.

Tropical Journal of Pharmaceutical Research is indexed by Science Citation Index (SciSearch), Scopus, International Pharmaceutical Abstract, Chemical Abstracts, Embase, Index Copernicus, EBSCO, African Index Medicus, JournalSeek, Journal Citation Reports/Science Edition, Directory of Open Access Journals (DOAJ), African Journal Online, Bioline International, Open-J-Gate and Pharmacy Abstracts

\section{INTRODUCTION}

The use of medicinal plants to treat diseases is as old as human civilization. Synthetic drugs are very expensive to develop. On the contrary, many medicines of plant origin have been used foe centuries without any undesirable effects. It is therefore essential that efforts should be made to introduce new medicinal plants to develop new drugs [1]. Since medicinal plants are believed to be an important source of novel chemical substances with potential remedial effects, they 
are used in Bangladesh traditional medical practice for the treatment of various diseases [2]. Dimocarpus longan Lour. syn. Euphoria Iongana Lam. (locally known as Longan fruit) is a subtropical evergreen tree of Sapindaceae family, extensively grown in southern China, India and South East Asia [3]. The appearances of the fruits are similar to those of lychee, but are smaller, smoother and yellow-tan in colour. The color of fleshy aril is white to off-white or pinkish which surrounds a red brown, brown to black seed, which separates easily from the flesh. Its fruit is accepted by consumers over the world due to its sweet and juicy sensation in the mouth and its health benefits. Longan fruit is rich in carbohydrates, protein, fiber, fat, vitamin C, amino acids, and minerals. 4 The fruit has been used traditionally in Chinese medicinal formulations, serving as a agent for the relief of neural pain and swelling5. In recent years, the extracts from longan fruit including aril, pericarp and seed, have exhibited excellent antioxidant ability, anti-tyrosinase, anticancer, antifatigue and hypoglycemic activities [4-14].

Longan seeds are used to prevent pain, hemorrhage, hernia, and skin diseases in Chinese folk medicine [14]. The seeds act as antioxidant [], prevent human colorectal carcinoma cells [4], and they contain gallic acid, ellagic acid,and corilagin [9]. The current study was undertaken to investigate the analgesic, CNS depressant and anti-diarrheal effects of some solvent extracts of the seeds of $D$. longan.

\section{EXPERIMENTAL}

\section{Collection and identification of plant}

Fresh fruits of $D$. longan were collected from Dhaka, Bangladesh in August, 2012. The fresh fruits of $D$. longan were identified by $\mathrm{Dr}$ Mahbubur Rahaman, Associate Professor, Department of Botany, Rajshahi University, Rajshahi and National Herbarium of Bangladesh, with voucher specimen no. 36664. The seeds were separated from the fruits, dried for one week and pulverized into a coarse powder with a suitable grinder (Palm Leaf Grinder PK 300). The powder was stored in an airtight container, and kept in a cool, and dry place pending analysis.

\section{Drugs}

Diazepam, indomethacin and loperamide were obtained from Square Pharmaceuticals Ltd., Bangladesh

\section{Preparation of extract}

The dried seed powder (500 g) was soaked in $500 \mathrm{ml}$ of $95 \%$ ethanol for 7 days in cold condition with occasional shaking. The whole mixture was successively filtered through a piece of clean, white cotton material and filter paper. The filtrate was divided into two equal portions; one portion was further partitioned by solventsolvent extraction with petroleum ether, chloroform and ethyl acetate and other portion was dried. After multiple extractions all filtrates were further evaporated to dryness to obtain the dried crude extracts. The ethanol, petroleum ether, chloroform and ethyl acetate extracts were tagged ENLS, PELS, CHLS and EALS, respectively.

\section{Phytochemical analysis}

The crude extracts were subjected to qualitative phytochemical screening using standard procedures [15].

\section{Animals}

Long-Evans rats (8 to 14 weeks old) of either sex weighing about $80-120 \mathrm{~g}$ and were used to conduct the research. The rats were procured from the animal research branch of the International Centre for Diarrhoeal Disease and Research, Bangladesh (ICDDRB). They were kept under standard environmental conditions $\left(24.0 \pm 0{ }^{\circ} \mathrm{C}\right.$ and $55-65 \%$ relative humidity with a $12 \mathrm{~h}$ light/dark cycle) for two weeks for acclimatization. They were fed ICDDRB formulated rodent food and had access to tap water ad libitum. All the animals were fasted over night prior to each test but had free access to water.

\section{Ethical approval}

The guidelines followed for animal experiment were accepted by the Southeast University institutional animal ethical committee [16].

\section{CNS depressant activity}

CNS depressant activity was assessed usng both the hole cross and open field tests.

\section{Hole cross test}

The aim of this study was to examine the effect of the extract on the emotional behavior of the rodents using the hole-board test. The method of Takagi et al. [17] was followed. A steel partition with a hole of $3 \mathrm{~cm}$ diameter fixed in the middle of a cage having a size of $30 \times 20 \times 14 \mathrm{~cm}$ was 
used. The number of times a rat passed through the hole from one chamber to other was counted for a period of $3 \mathrm{~min}$ at $0,30,60,90$ and $120 \mathrm{~min}$ after oral administration of normal saline (10 $\mathrm{ml} / \mathrm{kg}$ ), experimental crude extracts (at dose of $200 \mathrm{mg} / \mathrm{kg}$ and $300 \mathrm{mg} / \mathrm{kg}$ ) and diazepam as standard drug $(1 \mathrm{mg} / \mathrm{kg})$

\section{Open field test}

This experiment evaluates a range of anxietyinduced locomotor activity and exploratory actions. The animals were treated at the as stated above and at the same doses. The test was performed according to Gupta et al [18]. The floor of an open field of half square meter was divided into a series of squares, each colored alternatively black and white. The apparatus had a $40 \mathrm{~cm}$ wall. The number of squares visited by the animals was calculated for $3 \mathrm{~min}$, at 0,30 , 60,90 and $120 \mathrm{~min}$ subsequent to oral administration of the normal saline $(10 \mathrm{ml} / \mathrm{kg})$, experimental crude extracts (doses) $(200 \mathrm{mg} / \mathrm{kg}$ and $300 \mathrm{mg} / \mathrm{kg}$ ) and diazepam as standard drug $(1 \mathrm{mg} / \mathrm{kg}$.)

\section{Evaluation of analgesic activity}

To assess the analgesic activity of the extracts, acetic acid-induced writhing and formalininduced pain tests were used.

\section{Acetic acid-induced writhing test}

In this test, acetic acid was given intraperitoneally to generate pain sensation [19]. Indomethacin $(10 \mathrm{mg} / \mathrm{kg})$ was used as standard. The plant extracts were administered orally at 200 and $300 \mathrm{mg} / \mathrm{kg}$ doses to test rats after an overnight fast. The extracts, normal saline and standard drug were administered orally $30 \mathrm{~min}$ prior to intraperitoneal administration of $0.7 \% \mathrm{v} / \mathrm{v}$ acetic acid solution $(0.1 \mathrm{ml} / 10 \mathrm{~g})$. [19]The rodents were placed individually on an observation table to count the writhings made in 15 min commencing just $5 \mathrm{~min}$ after intraperitoneal administration of acetic acid. The animals did not always give full writhing, sometimes they started to give but they did not complete it. This unfinished writhing was counted as half-writhing. Hence, two half-writhings were taken as one complete writhing. The number of writhes in each treated group was compared to those of the control and standard groups.

\section{Formalin test}

The antinociceptive activity of the extracts was determined using formalin test [20]. Control group received normal saline and $20 \mu$ of $5 \%$ formalin while the test groups and positive control groups received tested extracts (200 and $300 \mathrm{mg} / \mathrm{kg}$, p.o.) and reference drug, indomethacin $(10 \mathrm{mg} / \mathrm{kg}) 60$ minutes before injection of $20 \mu \mathrm{l}$ of $5 \%$ formalin into the dorsal surface of the right hind paw. The rats were monitored for $30 \mathrm{~min}$ after the injection of formalin, and the amount of time spent licking the injected hind paw was recorded. The first $5 \mathrm{~min}$ post-formalin injection is referred to as the early phase and the tenure between 15 and 30 min as the late phase. The total time spent licking or biting the wounded paw (pain response) was determined with the aid of a stop watch.

\section{Anti diarrheal tests}

Anti-diarrheal effect was evaluated usng castor oil- and magnesium sulphate-induced diarrheal methods.

\section{Castor oil-induced diarrhea test}

Awouter et al [21] method was used for this test. Fifty rats were fasted for $18 \mathrm{~h}$ with free access to water and randomly separated into ten groups of five rodents each. Each extract was administered orally at 200 and $300 \mathrm{mg} / \mathrm{kg}$ doses. Group-I (control) received only normal saline $(5 \mathrm{ml} / \mathrm{kg})$, while group 2 received loperamide $(3 \mathrm{mg} / \mathrm{kg}$ ) as standard. One hour later, each animal received 1 $\mathrm{ml}$ of castor oil orally by gavage. Feces were collected with an absorbent sheet of paper placed below the transparent cages, the total number of diarrheal feces expelled in $4 \mathrm{~h}$ were compared with both the standard and control groups. The total score of diarrheal faeces for the control group was considered as $100 \%$. The results were expressed as \% inhibition of diarrhea.

\section{Magnesium sulphate-induced diarrhea test}

This test was performed in a similar way to the above method. Here, diarrhea was induced by oral administration of magnesium sulphate [22](2 $\mathrm{mg} / \mathrm{kg}$ ) to the animals $30 \mathrm{~min}$ after oral pre-treatment with vehicle (1\% Tween 80 in water, $10 \mathrm{ml} / \mathrm{kg}$, p.o.) to the control group, loperamide $(3 \mathrm{mg} / \mathrm{kg}$ ) to the positive control group; the plant extracts were given at 200 and $300 \mathrm{mg} / \mathrm{kg}$ doses to the test groups.

\section{Statistical analysis}

Data are expressed as mean \pm SEM and evaluated by analysis of variance (ANOVA) followed by Dunnet's multiple comparisons test, using SPSS 15.00 (USA). Differences between means for various groups were considered significant at $p<0.01$. 


\section{RESULTS}

\section{Phytochemical profile of extracts}

The extracts gave positiveresults for tannins, alkaloids, and flavonoids.

\section{CNS depressant activity}

Rodents treated with different solvent extracts at two doses (200 and $300 \mathrm{mg} / \mathrm{kg}$ ) showed dose dependent reduction in the locomotor activity comparable with the standard drug, diazepam ( $p$ $<0.01$, Table 1). The control group showed insignificant change in locomotor activity ( $p<$ 0.01).

\section{Analgesic activity of the extracts}

Table 3 shows the effects of the extracts on acetic acid-induced writhing in rats. Both doses of the extracts showed significant reduction $(p<$
0.01) in writhing after oral administration. The extracts seemed to be more potent than the reference drug.

In the antinociceptive test based on the formalin model, the extracts significantly $(p<0.01)$ suppressedlicking activity in both phases of pain (Table 4) in a dose-dependant manner. Standard.

\section{Antidiarrhoeal activity}

In the castor oil-induced diarrhea model, all the extracts at both doses significantly diminished the total number of diarrhoeial feces in a dosedependent manner $(p<0.01$, Table 5).

In the magnesium sulphate-induced diarrhea, pretreatment of rats with the different doses of the extracts caused significant dose-dependent decrease in the frequency of purging $(p<0.01$, Table 6).

Table 1: CNS depressant activity of extracts in rats (hole cross method)

\begin{tabular}{|c|c|c|c|c|c|c|}
\hline \multirow[t]{2}{*}{ Treatment } & \multirow{2}{*}{$\begin{array}{l}\text { Dose } \\
\text { (mg/kg) }\end{array}$} & \multicolumn{5}{|c|}{ No. of movements } \\
\hline & & $0 \min$ & $30 \mathrm{~min}$ & $60 \mathrm{~min}$ & $90 \mathrm{~min}$ & $120 \min$ \\
\hline $\begin{array}{l}1 \% \text { Tween } 80 \text { in } \\
\text { water }\end{array}$ & $10 \mathrm{ml} / \mathrm{kg}$ & $17 \pm 0.57$ & $16 \pm 0.51$ & $14.33 \pm 0.55$ & $13.5 \pm 0.84$ & $12.17 \pm 0.30$ \\
\hline Diazepam & 1 & $15.5 \pm 0.71$ & $6.67 \pm 0.49^{*}$ & $4.17 \pm 0.40^{*}$ & $2.33 \pm 0.21 *$ & $1.17 \pm 0.30^{*}$ \\
\hline $\begin{array}{l}\text { ENLS } \\
\text { ENLS }\end{array}$ & $\begin{array}{l}200 \\
300\end{array}$ & $\begin{array}{l}13.6 \pm 1.28 \\
12.2 \pm 0.79^{*}\end{array}$ & $\begin{array}{l}6.5 \pm 0.56^{\star} \\
5.2 \pm 0.47^{\star}\end{array}$ & $\begin{array}{l}4.2 \pm 0.30^{*} \\
4 \pm 0.36^{*}\end{array}$ & $\begin{array}{l}2.33 \pm 0.21^{*} \\
2.66 \pm 0.33^{*}\end{array}$ & $\begin{array}{l}1.83 \pm 0.30^{*} \\
1.67 \pm 0.21^{*}\end{array}$ \\
\hline $\begin{array}{l}\text { PELS } \\
\text { PELS }\end{array}$ & $\begin{array}{l}200 \\
300\end{array}$ & $\begin{array}{l}15.3 \pm 0.88 \\
14.5 \pm 0.92\end{array}$ & $\begin{array}{l}3.67 \pm 0.33^{*} \\
5.83 \pm 0.47^{*}\end{array}$ & $\begin{array}{l}2.83 \pm 0.30^{*} \\
4.33 \pm 0.33^{*}\end{array}$ & $\begin{array}{l}1.33 \pm 0.21^{*} \\
2.5 \pm 0.34^{*}\end{array}$ & $\begin{array}{l}1.16 \pm 0.16^{*} \\
1.33 \pm 0.21^{*}\end{array}$ \\
\hline $\begin{array}{l}\text { CHLS } \\
\text { CHLS }\end{array}$ & $\begin{array}{l}200 \\
300\end{array}$ & $\begin{array}{l}13.3 \pm 0.33^{*} \\
10.5 \pm 0.22^{*}\end{array}$ & $\begin{array}{l}7.33 \pm 0.33^{*} \\
6.8 \pm 0.40 *\end{array}$ & $\begin{array}{l}5.33 \pm 0.33^{*} \\
5.5 \pm 0.22^{*}\end{array}$ & $\begin{array}{l}3.2 \pm 0.30^{*} \\
2.67 \pm 0.33^{*}\end{array}$ & $\begin{array}{l}1.67 \pm 0.21^{*} \\
1.33 \pm 0.21^{*}\end{array}$ \\
\hline EALS & 200 & $15.3 \pm 0.40$ & $6.5 \pm 0.22^{*}$ & $3.5 \pm 0.22^{*}$ & $2.33 \pm 0.21^{*}$ & $1.17 \pm 0.16^{*}$ \\
\hline EALS & 300 & $11.83 \pm 0.65^{*}$ & $5.66 \pm 0.33^{*}$ & $3.33 \pm 0.21^{*}$ & $2.17 \pm 0.30^{*}$ & $0.83 \pm 0.30^{*}$ \\
\hline
\end{tabular}

All values are expressed as mean \pm SD $(n=6) ;{ }^{*} p<0.01$, significant compared to control. In this test, all extracts exhibited a perceptible decline in locomotion of test animals at $2^{\text {nd }}$ observation $(30 \mathrm{~min})$ which continued up to $4^{\text {th }}$ observation period $(120 \mathrm{~min})$ at both dose levels (200 and $300 \mathrm{mg} / \mathrm{kg}$ body weight). The results were dose dependent and statistically significant $(P<0.01)($ Table-2).

Table 2: CNS depressant activities of plant extracts in rats (open field method)

\begin{tabular}{|c|c|c|c|c|c|c|}
\hline \multirow[t]{2}{*}{ Treatment } & \multirow{2}{*}{$\begin{array}{l}\text { Dose } \\
\text { (mg/kg) }\end{array}$} & \multicolumn{5}{|c|}{ No. of movements } \\
\hline & & 0 min & $30 \mathrm{~min}$ & $60 \mathrm{~min}$ & 90 min & 120 min \\
\hline $\begin{array}{l}1 \% \text { Tween } 80 \text { in } \\
\mathrm{H}_{2} \mathrm{O}\end{array}$ & $10 \mathrm{ml} / \mathrm{kg}$ & $151.8 \pm 1.99$ & $150.5 \pm 1.58$ & $149.8 \pm 2.41$ & $147.7 \pm 1.28$ & $145.6 \pm 1.45$ \\
\hline Diazepam & 1 & $161.2 \pm 3.32^{*}$ & $86.2 \pm 1.10^{*}$ & $64.3 \pm 1.33^{*}$ & $43.8 \pm 1.13^{*}$ & $12.3 \pm 0.84^{*}$ \\
\hline ENLS & 200 & $167.5 \pm 1.33^{*}$ & $122.8 \pm 1.2^{*}$ & $89.7 \pm 1.20^{*}$ & $61.8 \pm 1.51^{*}$ & $11.6 \pm 0.61^{*}$ \\
\hline ENLS & 300 & $161.3 \pm 1.76^{*}$ & $105.8 \pm 2.15^{*}$ & $77.8 \pm 0.70^{*}$ & $54.2 \pm 1.19^{*}$ & $10.8 \pm 0.30^{*}$ \\
\hline PELS & 200 & $158.5 \pm 2.06$ & $82.7 \pm 1.33^{*}$ & $65.2 \pm 1.01^{*}$ & $44.5 \pm 0.92^{*}$ & $15.3 \pm 2.10^{*}$ \\
\hline PELS & 300 & $153.7 \pm 0.55$ & $80.5 \pm 0.76^{*}$ & $43.2 \pm 1.01^{*}$ & $38.3 \pm 1.11^{*}$ & $11.7 \pm 0.55^{*}$ \\
\hline CHLS & 200 & $163.7 \pm 0.49^{*}$ & $84.8 \pm 0.60^{*}$ & $47.2 \pm 0.60^{*}$ & $37.5 \pm 0.92^{*}$ & $13.3 \pm 1.05^{*}$ \\
\hline CHLS & 300 & $155.3 \pm 0.80$ & $80.5 \pm 1.56^{*}$ & $41.3 \pm 1.05^{*}$ & $33.2 \pm 0.70^{*}$ & $10.8 \pm 0.40^{*}$ \\
\hline EALS & 200 & $162.3 \pm 0.98^{*}$ & $84.3 \pm 0.33^{*}$ & $43.8 \pm 0.70^{*}$ & $36.8 \pm 1.95^{\star}$ & $13.5 \pm 0.84^{*}$ \\
\hline EALS & 300 & $154.3 \pm 0.55$ & $79.8 \pm 1.07^{*}$ & $38.8 \pm 0.47^{*}$ & $32.8 \pm 0.60^{*}$ & $11.8 \pm 0.30^{*}$ \\
\hline
\end{tabular}


Table 3: Analgesic activity of extracts by acetic acid-induced writhing method

\begin{tabular}{|c|c|c|c|}
\hline Treatment & Dose (mg/kg) & No. of writhings & \% Inhibition \\
\hline $\begin{array}{l}1 \% \text { Tween } 80 \\
\text { in water }\end{array}$ & $0.1 \mathrm{ml} / 10 \mathrm{~g}$ & $24.50 \pm 1.43$ & 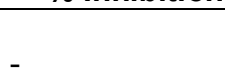 \\
\hline Indomethacin & 10 & $10.17 \pm 0.79^{*}$ & 58.50 \\
\hline ENLS & 200 & $7.67 \pm 1.15^{*}$ & 68.69 \\
\hline ENLS & 300 & $5.50 \pm 0.84^{*}$ & 77.55 \\
\hline PELS & 200 & $6.83 \pm 1.08^{*}$ & 72.12 \\
\hline PELS & 300 & $2.83 \pm 0.30^{*}$ & 88.45 \\
\hline CHLS & 200 & $9.17 \pm 0.47^{*}$ & 62.57 \\
\hline CHLS & 300 & $4.50 \pm 0.22^{*}$ & 81.63 \\
\hline EALS & 200 & $9.33 \pm 2.02^{*}$ & 61.92 \\
\hline EALS & 300 & $4.33 \pm 0.21^{*}$ & 82.33 \\
\hline
\end{tabular}

Table 4: Analgesic activity of extracts based on formalin-induced writhing method

\begin{tabular}{llll}
\hline Treatment & Dose $(\mathbf{m g} / \mathbf{k g})$ & Early phase $(\mathbf{s})$ & Late phase $(\mathbf{s})$ \\
\hline Water & $10 \mathrm{ml} / \mathrm{kg}$ & $25.17 \pm 0.86$ & $42.50 \pm 0.71$ \\
Indomethacin & 10 & $12.83 \pm 0.30^{*}$ & $24.00 \pm 0.516^{*}$ \\
ENLS & 200 & $13.67 \pm 0.49^{*}$ & $20.83 \pm 0.30^{*}$ \\
ENLS & 300 & $11.83 \pm 0.30^{*}$ & $17.83 \pm 0.40^{*}$ \\
PELS & 200 & $14.50 \pm 0.22^{*}$ & $20.50 \pm 0.34^{*}$ \\
PELS & 300 & $12.67 \pm 0.21^{*}$ & $18.00 \pm 0.36^{*}$ \\
CHLS & 200 & $14.17 \pm 0.40^{*}$ & $20.50 \pm 0.22^{*}$ \\
CHLS & 300 & $12.67 \pm 0.49^{*}$ & $16.17 \pm 0.40^{*}$ \\
EALS & 200 & $15.33 \pm 0.21^{*}$ & $21.17 \pm 0.47^{*}$ \\
EALS & 300 & $13.50 \pm 0.22^{*}$ & $17.50 \pm 0.34^{*}$ \\
\hline
\end{tabular}

All values are expressed as mean \pm STD ( $n=6)$; ANOVA followed by Dunnet's test. ${ }^{*} P<0.01$ significant compared to control.

Table 5: Effect of the extracts on castor oil-induced diarrhoea

\begin{tabular}{llll}
\hline Treatment & Dose $\mathbf{( m g / k g )}$ & $\begin{array}{l}\text { Total no of diarrhoeial } \\
\text { faeces in } \mathbf{4} \mathbf{~}\end{array}$ & Inhibition (\%) \\
\hline Normal saline & 5 & $20.5 \pm 1.08$ & - \\
Reference & 2 & $9.33 \pm 0.80^{*}$ & 54.48 \\
ENLS & 200 & $12.83 \pm 0.60^{*}$ & 37.41 \\
ENLS & 300 & $8.33 \pm 0.66^{*}$ & 59.37 \\
PES & 200 & $13.8 \pm 0.47^{*}$ & 32.68 \\
PES & 300 & $8.16 \pm 0.30^{*}$ & 60.20 \\
CHLS & 200 & $15.16 \pm 0.65^{*}$ & 26.05 \\
CHLS & 300 & $7.50 \pm 0.65^{*}$ & 63.41 \\
EAS & 200 & $13.33 \pm 0.42^{*}$ & 34.98 \\
EAS & 300 & $8.16 \pm 0.40^{*}$ & 60.20 \\
\hline
\end{tabular}

All values are expressed as mean $\pm S D(n=6)$; (ANOVA) followed by Dunnet's test; ${ }^{*} p<0.01$ significant compared to control 


\section{DISCUSSION}

In the current study, we have evaluated the CNS depressant, analgesic and antidiarrheal effects of various solvent extracts of the seeds of $D$. longan in rodents. In vivo methods using intact animal models are thought to be good method for examining the action of drugs on the central nervous system. The most significant step in assessing drug action on the CNS is to monitor locomotor activity of the test models. To obtain evocative results regarding the activity of $D$. longan seeds extracts on the CNS of rats, two tests, namely hole cross and open field, were performed. The movement is a measure of the level of excitability of the CNS [23] and its decrease may be intimately related to sedation resulting from depression of the CNS [24].
All the extracts significantly decreased this activity as revealed by the results of the two aforementioned tests. Sedation may be due to interaction with benzodiazepines-like compounds. The seed extracts might have acted by potentiating GABAergic inhibition in the CNS by membrane hyperpolarization which diminish the firing rate of critical neurons in the brain or may be due to direct activation of GABA receptor by the extracts [24]. Previous investigation on phytoconstituents and plants indicate that many flavonoids and neuroactive steroids are ligands for $\mathrm{GABA}_{\mathrm{A}}$ receptors in the central nervous system, which led to the postulation that they can act as benzodiazepine [25]. Therefore, the phytoconstituents (tannin, alkaloids, flavonoids) may be responsible for their CNS depressant activity.

Table 6: Effect of the extracts on magnesium sulphate-induced diarrhea

\begin{tabular}{llll}
\hline Treatment & $\begin{array}{l}\text { Dose } \\
(\mathbf{m g} / \mathbf{k g})\end{array}$ & $\begin{array}{l}\text { Total no. of } \\
\text { diarrhoeial faeces } \\
\text { in 4 h }\end{array}$ & Inhibition (\%) \\
\hline (Control) & Water & $20.5 \pm 1.08781$ & - \\
(Standard) & 2 & $9.33 \pm 0.73^{*}$ & 54.48 \\
(ENLS) & 200 & $16.16 \pm 0.60^{*}$ & 21.17 \\
(ENLS) & 300 & $7.83 \pm 0.60^{*}$ & 61.80 \\
(PES) & 200 & $14.16 \pm 0.47^{*}$ & 30.92 \\
(PES) & 300 & $7.16 \pm 0.30^{*}$ & 65.07 \\
(CHLS) & 200 & $16.33 \pm 0.30^{*}$ & 20.34 \\
(CHLS) & 300 & $8.33 \pm 0.33^{*}$ & 59.37 \\
(EAS) & 200 & $13.8 \pm 0.33^{*}$ & 32.68 \\
(EAS) & 300 & $8.16 \pm 0.30^{*}$ & 60.20 \\
\hline
\end{tabular}

All values are expressed as mean $\pm S D(n=6) ;($ ANOVA) followed by Dunnet's test;

${ }^{*} p<0.01$ significant compared to control

To ascertain analgesic activity, we performed both acetic acid-induced writhing and formalininduced pain tests. The first method is extensively used for the assessment of peripheral antinociceptive activity [26]. It is very sensitive and able to detect anti-nociceptive effect of compounds at dose levels that may appear inactive in other methods such as the tailflick test [27]. The method has been associated with prostanoids in general, e.g., increased levels of PGE2, PGF2 $\alpha$ and lipoxygenase products in peritoneal fluids $[28,29]$. Therefore, the results of the acetic acid induced writhing; strongly suggest that the mechanism of action of these extracts may be linked partly to lipoxygenase or cyclooxygenase pathways.

Again, the second test is useful for elucidating mechanism of pain and analgesia. Drugs that principally act centrally such as narcotics hinder both phases of formalin-induced pain while peripherally-acting drugs such as indomethacin inhibit only the second phase [29]. Since the extracts exerted significant dose-related inhibition of both phases in the formalin-induced pain model, this probably indicates that the overall antinociceptive effect of the crude extracts involves central and peripheral mechanism. Indomethacin produced significant decline in the pain response of the rodents but the effect was chiefly noticed in the second phase of pain which is consistent with earlier reports that NSAIDs are efficient only in the second phase of the formalin test.[30]

Our investigation also points to an antidiarrheal activity of the extracts. The effect was close to that of the higher dose of the standard drug, loperamide. Castor oil produces diarrhea via ricinoleic acid [31] which elevates prostaglandin 
biosynthesis. Prostaglandin participates in the patho-physiological functions in the GIT [32]. The extracts reduced this diarrhea probably through the inhibition of prostaglandin biosynthesis. On the other hand, magnesium sulphate accelerates the liberation of cholecystokinin from duodenal mucosa, which extends the secretion and motility of small intestine [33]. The extracts reduced the diarrheia, perhaps by increasing the absorption of water and electrolyte from GIT.

\section{CONCLUSION}

All the seed extracts of $D$. longan fruits investigated have potent CNS depressant, analgesic (both central and peripheral) and antidiarrheal activities. However, further research is needed to determine the precise mechanisms involved as well as the chemical constituents responsible for the pharmacological activities.

\section{REFERENCES}

1. Ikram M. Economic potential of medicinal plants.Hamdard Medicus 1983; 26: 16-17,

2. Rashid MA, Hasan CM, Choudhury SAR, Begum B, Rahman S. Ethnopharmacological investigation of medicinal plants of Bangladesh. Bangladesh J. Physiol.Pharmacol 1997; 12: 25-29

3. Jiang $Y$, Zhang Z, Joyce DC, Ketsa S. Postharvest biology and handling of longan fruit (Dimocarpus longan Lour.). Postharvest Bio. Technol. 2002; 26 : 241-252.

4. Rangkadilok N, Sitthimonchai S, Worasuttayangkurn L, Mahidol C, Ruchirawat $M$, Satayavivad J. Evaluation of free radical scavenging and antityrosinase activities of standardized longan fruit extract. Food Chem. Toxicol. 2007; 45 2): 328336.

5. Chung YC, Lin CC, Chou CC, Hsu CP. The effect of longan seed polyphenols on colorectal carcinoma cells. Euro. J. Clinical Invest. 2010; 40: 713-721.

6. De Assis SA, Vellosa JCR, Brunetti IL, Khalil NM, Leite $K M D C$, Martins $A B G$, Oliveira OMMD. Antioxidant activity, ascorbic acid and total phenol of exotic fruits occurring in Brazil. Int. J. Food Sci. Nut. 2009; 60:439-448.

7. ParkS J, Park D H, Kim DH, Lee S, Yoon BH, Jung WY, Lee KT, Cheong JH, Ryu JH. The memoryenhancing effects of Euphoria longan fruit extract in mice. J. Ethnopharmacol 2010; 128:160-165.

8. Prasad KN, Hao J, Shi J, Liu T, Li J, Wei XY, Qiu SX, Xue S, Jiang YM. Antioxidant and anticancer activities of high pressure-assisted extract of longan (Dimocarpus longan Lour.) fruit pericarp. Innovative Food Sci. Emerging Tech. 2009; 10: 413-419.

9. Soong $Y Y$, Barlow PJ. Isolation and structure elucidation of phenolic compounds from longan (Dimocarpus lognan Lour.) seed by high-performance liquid chromatography-electrospray ionization mass spectrometry. J Chromatogr A 2005; 1085: 270 277.

10. Yang B, Zhao MM, Jiang YM. Anti-glycated activity of polysaccharides of longan (Dimocarpus longan Lour.) fruit pericarp treated by ultrasonic wave. Food Chem. 2009; 114: 629-633.

11. Yang B, Zhao MM, Shi J, Cheng GP, Ruenroengklin N, Jiang YM. Variations in water-soluble saccharides and phenols in longan fruit pericarp after drying. J. Food Proc. Eng. 2008; 31: 66-77.

12. Zheng $S Q$, Jiang F, Gao HY, Zheng JG. Preliminary observations on the antifatigue effects of longan (Dimocarpus longan Lour.) seed polysaccharides. Phytother Res 2010; 24(4): 622-624.

13. Huang RQ, Zou YX, Liu XM. Study on the hypoglycemic effect of longan seed extract. Nat. Prod. Res. Dev. 2006; 18: 991-992.

14. Trease G, Evans M. Pharmacopoeial and related drugs of biological origin. In: A Textbook of Pharmacognosy. 15th ed. London:WB Saunders;2001; pp 262-270.

15. Zimmermann M. Ethical guidelines for investigations of experimental pain in conscious animals. Pain. 1983; 16: 109.-110

16. Takagi $K$, Watanabe $M$, Saito $H$. Studies on the spontaneous movement of animals by the hole cross test: Effect of 2-dimethylaminoethane. Its acylates on the central nervous system. Jpn. J. Pharmacol. 1971; 21: 797-810.

17. Gupta BD, Dandiya PC, Gupta ML. A psychopharmacological analysis of behavior in rat. Jpn. J. Pharmacol. 1971; 21: 293-298.

18. Ahmed M, Shikha HA, Sadhu SK, Rahman MT, Datta BK. Analgesic, diuretic, and anti-inflammatory principle from Scoparia dulcis. Pharmazie. 2001; 56(8): 657-660.

19. Sharma A, Bhatial S, Kharyaz MD, Gajbhiye V, Ganesh $N$, Namdeo AG, Mahadik KR. Anti-inflammatory and analgesic activity of different fractions of Boswellia serrata. Int. J. Phytomed. 2010; 2: 94-99.

20. Awouter F, Neimegeers CJE, Lenaert FM, Janssen PAJ. Delay of castor oil diarrhoea in rats; $A$ new way to evaluate inhibitors of prostaglandin's biosynthesis. J. Pharm Pharmacol. 1978; 30: 4145.

21. Doherty SS. Inhibition of arachidonic acid release, mechanism by which glucocorticoids inhibit endotoxin-induced diarrhoea. $\mathrm{Br} J$ Pharmacol. 1981;73:549-554

22. Masur RM, Martz W, Carlini EA. Effects of acute and chronic administration of Cannabis satis and (-) 9trans tetra hydro cannabinaol on the behavior of rats in open field arena. Psychopharmacol. 1980; 2: 5-7.

23. Ozturk Y, Aydini S, Beis R, Baser KHC, Berberoglu $H$. Effect of Hypericum pericum L. and Hypericum calycinum $I$. extracts on the central nervous system in mice, Phytomed.1996; 3(2): 139-146.

24. Kolawole OT, Makinde JM, Olajide OA. Central nervous depressant activity of Russelia equisetiformis. Nig. J. Physiol. Sci. 2007; 22: 59-63.

25. Verma A, Jana GK, Sen S, Chakraborty R, Sachan S, Mishra A. Pharmacological evaluation of Saraca indica Leaves for central nervous system depressant activity in mice. J. Pharm. Sci. Res. 2010; 2(6): 338-343.

26. Gene' RM, Segura L, Adzet T, Marin E, Inglesias, J.. Heterotheca inuloides: anti-inflammatory and analgesic effects. J. Ethnopharmacol. 1998; 60: 157-162.

27. Bentley GA, Newton SH, Starr J. Evidence for action of morphine and enkephalins on sensory nerve endings in the mouse peritoneum. Br. J. Pharmacol. 1981; 73: 325-332.

28. Derardt $R$, Jongney $S$, Delvalcee F, Falhout M. Release of prostagladdins $E$ and $F$ in an algogenic reaction and its inhibition. Eur. J. Pharmacol. 1980; 51: 1724.

29. Dhara AK, Suba V, Sen $T$, Pal S, Chaudhuiri AK. Preliminary studies on the anti- inflammatory and analgesic activity of methanolic fraction of the root of Tragia involucrate. J. Ethnopharmacol. 2000; 72: 265-268. 
30. Santos FA, Rao VSN, Silveira ER. Investigation on the antinociceptives of Psidium guajava leaf essential oil and its major constituents. Phytother. Res. 1998; 12: 24-27.

31. Mascolo N, Izzo AA, Autore G, Barbato F, Capasso F Nitric oxide and castor oil induced diarrhoea.J. Pharmacol. Exp. Ther. 1994; 268:291-295.

32. Capasso F, Mascolo N, Izzo AA, Gaginella TS. Dissociation of castor oil-induced diarrhoea and intestinal mucosal injury in rat: effect of $N^{G}$-nitro-Larginine methyl ester. Br. J Pharmacol 1994; 113: 1127-1130.

33. Zavala MA, Perez S, Perez C, Vargas R, Perez RM. Antidiarrheal activity of Waltheria americana, Commelina coelestis and Alternanthera repens. J. Ethanopharmacol. 1998; 61: 41-47 